\title{
A Zselic digitális lábnyomai. Webes és közösségimédia-kutatás a régió platformjairól és reprezentációjáról
}

\author{
Digital footprints of Zselic. Web-based and social media \\ research about the region's platforms and representations
}

\author{
FEHÉR KATALIN
}

FEHÉR Katalin: tudományos fömunkatárs, Budapesti Gazdasági Egyetem Kutatóközpont; 1165 Budapest, Diósy L. u. 22-24.; feher.katalin@uni-bge.hu, info@feherkatalin.hu

KULCSSZAVAK: digitális lábnyom; a régió identitása; regionális identitás; digitális identitás; közösségi média; web; alkalmazás

ABSZTRAKT: A Zselic digitális lábnyomát hálózatkutatási módszertannal vizsgáló projekt célja az volt, hogy összegezze, elemezze és felmutassa a régió már felépült azonosítóit, webes, közösségi és témahálózatait, illetve reprezentációit. Cél volt továbbá erre alapozva ajánlásokat megfogalmazni egy konstruktív, célzott üzenetekre épülő digitális identitás felépítéséhez, mely online eszközökkel támogatja a térség turizmusát, gazdaságát, kulturális és természeti értékeinek védelmét és közösségeinek komfortját.

A kutatás két alapkérdésre épül. Az első alapkérdés, hogy tartozik-e a Zselic régió digitális identitásához egységes platform-, adat- vagy reprezentációs azonosítókészlet. A második alapkérdés, hogy melyek azok az interaktív platformok, ahol a Zselic regionális digitális identitása reprezentálódik. Vizsgáltuk azokat az azonosító funkciókat, témahálózatokat és reprezentációkat, melyek a térség digitális identitását hosszabb távon meghatározzák. Vizsgáltuk továbbá azokat az interaktív, kezdeményező és újításokra nyitott megoldásokat is, melyek hálózatokat és közösségeket építenek, illetve erősítik a régió vonzerejét és életminőségét. A kutatás kevert mintavételi eljárással készült és megismételhető a tanulmány alapján. A gyorsan változó digitális környezetek és a folyamatosan frissülö tartalom- és adatfolyamok azonban különböző kimenetekhez vezethetnek. A kapott eredmények alapján a meglévő, jó keresési és találati előzményekkel bíró, tartalmilag és funkcionálisan összefoglaló jellegű webes csomópontok erősítése javasolt, valamint a régió közösségei integrált online felületekkel és hálózati összeköttetésekkel támogathatók. Emellett újítások bevezetése és a fiatalabb generációk platformjain való erősítés szükséges.

Katalin FEHÉR: senior research fellow, Research Centre, Budapest Business School University of Applied Sciences; Diósy L. u. 22-24., H-1165 Budapest, Hungary; feher.katalin@uni-bge.hu, info@feherkatalin.hu

KEYWORDS: digital footprint; identity of regions; regional identities; digital identity; social media; web; application

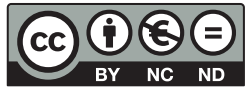


ABSTRACT: The goal of the digital footprint project was to summarize, analyze and present the Zselic region's current web and social media identifiers and online representations. It also aimed to give recommendations for a more integrated digital identity. Based on the results, it shows that constructive and targeted messages and highlighted online platforms support the region's tourist activity, economy, and its cultural and natural values. Moreover, by creating more opportunities and workplaces, and by making companies join further networks, these factors also enhance the comfort of regional communities. This project was preceded by another study with a stronger theoretical emphasis.

The study aims to answer two key questions. The first is: Can we find an integrated identification platform, data or representation set of the Zselic region? The second question is: Which interactive platforms and contents represent the digital identity of the Zselic region? Our research method was, on the one hand, focusing on keyword frequencies, search and hit rates and, on the other, content and representation analysis. The research process is repeatable. However, the constantly changing digital environment, the ongoing updated contents and data flow might produce different outputs.

Our results, nonetheless, did not point out an integrated or common platform acting as the Zselic region's single digital identity. On the other hand, we could recognize and analyze subject networks and regional profiles via well-defined web nodes and hubs, crosslinked contents, cumulative search and hit data, social media pages and visual representations. Based on these, we can draw up an interpretative and decisive web-based subject network defined by independent sources and their bottom-up or top-down communication. Our recommendations emphasize the strengths of the online communication about the Zselic region. We suggest that regional players need to focus on the strongest online nodes with functional or content summaries and with existing cumulative search and hit histories. Moreover, in order to increase the comfort of regional communities, it is necessary to facilitate their activities on social media platforms. Finally, the introduction of further innovations and the involvement of the younger generation will also be unavoidable.

\section{Bevezetés}

A regionális hálózatkutatás körébe tartozó, digitális identitást vizsgáló projekt abból indul ki, hogy a vizsgált térségnek, a Zselicnek vannak olyan online azonosítható identitásai és hálózati csomópontjai, webes tartalmi hangsúlyai és kísérletező-útkereső platformjai, melyek megkülönböztetik azt más térségektől. A Zselicről elérhető digitális lábnyomok, tematikus és tartalmi hálózatok szerteágazóak. Összefésülésük, rendszerezésük és elemzésük kevert mintavételi eljárásokkal történt, az eredményeket különböző módon szemléltetjük.

Ahhoz, hogy egy letisztult képet kapjunk és ajánlásokat fogalmazhassunk meg az internetes-digitális Zselic-reprezentáció sokszínűségéről, először a szakirodalom alapmegfontolásait kellett figyelembe venni (részletesen lásd Fehér 2015). Ezt követően került sor a probléma, a célkitűzés és a kutatási kérdések megfogalmazására. Az ajánlások erre a koncepcióra és az elvégzett online kutatás összesített eredményeire épülnek. Fontos kitétel: az itt olvasható kutatás a digitalizáció és az online kommunikációs trendek, illetve a folyamatosan változó, egymáshoz képest elmozduló hálózati csomópontok jelenlegi környezetében relevánsak. Felhasználás esetén szükséges figyelembe venni a digitális eszközés tartalomkörnyezet átalakulásait és frissíteni a kapott eredményeket. 


\section{Elméleti megfontolások a kutatáshoz}

A digitális identitás reprezentációi változékonyak. Valóságkonstrukciókként, illetve társadalmi konstrukciókként értelmezendők, melyek újra- és újratermelődnek (Faragó 2007; Gáspár 2005). A digitális hálózatokban elburjánzó adatok és üzenetrendszerek leképezik a valóságot, binárisan kódolják azt, majd a kódok komplex kapcsolatrendszerei a percepció számára újmédia-csomagolást kapnak, s ezek is összekapcsolódnak. Ami online és platformokon keresztül látszik, jelöl és megmutat, azonosít és reprezentál, illetve hálózatba szerveződik, kutatásunkban tehát vizsgálható és elemezhető.

Az adatrétegek mélysége folyamatosan nő: az adatrobbanást (big data) az internetes behálózottságnak, illetve a digitális eszközök és platformok terjedésének köszönhetjük. A weben és alkalmazásokon keresztüli adatáramlás, a többmilliárdos felhasználói tömeg keresései és találatai, a közösségi média, a videók és fotók, a mobil eszközök által forgalmazott adatok a jelenlegi módszertanokkal és szoftverekkel legfeljebb tíz százalék körüli adatfeldolgozást tesznek lehetővé (Gantz, Reinsel 2011), ebből is elsősorban a legálisan elérhető, a fősodorban megjelenő adatok feldolgozását. Kutatásunkban tehát a Zselic példája nem vizsgálható az összes digitalizált adat figyelembevételével. Itt visszatérünk az első pontra: a fókuszt a digitális identitás azon elemei jelentik, melyek nemcsak adatosítottak, hanem platformokon, keresőkben és a közösségi médiában megjelennek és ebben a formában elemezhetők. Mindezzel együtt hagyatkozunk az adatvezérelt döntések módszertanára is (Larose, Larose 2011).

A felhalmozódó adatkészleteink azonosítanak bennünket: az egyes adatkészletek, metaforikusan a digitális lábnyomok, azonosítják az entitásokat hálózataik dinamikájában (Fehér 2014). Az adatok keresőkben, weboldalakon, alkalmazásokon, multimédia-felületeken, közösségi hálózatokban, illetve szöveges-(audio)vizuális formákban kapnak struktúrát és dizájnt, fogyasztható tartalmat. Újmédia-felületek ezek, melyek bekeretezik a képernyőre írt adatokat. A fent említett valóságkonstrukciók itt teljesednek ki. Kutatásunkban ezekre a forrásokra hagyatkozunk.

A régió digitális identitása felől nézve a földrajzi/természeti értékek és a földrajzi-társadalmi identitás, a közigazgatás és a helyi szervezetek, a turizmus és a gazdaság, a kulturális örökség és a hagyományőrzés, valamint a vallási azonosítók adnak karakterisztikát aszerint, hogy mennyire publikusak, mennyire láthatók és elérhetők az online hálózatokban. Kutatásunk külön figyelmet szentel annak, hogy egy régió fejlettségét, vonzerejét, élhetőségét és életminőségét alapvetően meghatározzák azok az online is felfejthető, küldő nézőpontból is vizsgálható intézményesített, közösségi és személyes kapcsolatok, melyek a mindennapok komfortérzetét éppúgy meghatározzák, mint a jövőbeni lehetőségeket. A digitális platformokon vizsgálható eredmények ebben speciális szerepet játszanak: egyfelől az exponenciálisan digitalizálódó információtömeg lehetővé 
teszi, hogy a webes vagy web előtti időszakból származó információvagyon és tudásbank egy helyen legyen, néhány gombnyomással elérhetőkké váljanak az adatok az adott régióról. Másfelől a jelen hálózati kapcsolatait áthatják a múlt digitális lábnyomai.

Az eredmények tehát két dimenzióban kezelendők, s a lenti kutatás is ezeket követi:

- tágabb idővonalon, kumulált eredményekkel és összesített információbázisként;

- a jelen metszeteiként azokon a platformokon, melyek az interaktivitásra építenek.

Társadalmi, kulturális és gazdasági potenciált jelent a már meglévő, folyamatosan növekvő, kumulált eredmények átfogó értékelése. Ezek gyakran felülről jövő kommunikációs és adatáramlások: intézmények, vállalatok kezelik őket, hivatalos és ellenőrzött források. Emellett a jelen interakcióinak vizsgálata tárandó fel: alulról jövő kommunikáció magánszemélyek, közösségek, egyesületek, szervezetek részéről, melyek az aktuális áramlásokról és kapcsolatokról adnak pillanatképet (részletesebben lásd Fehér 2015).

\section{A kutatás kérdései, célja, módszertana és a kutatási korlátai}

Kutatási kérdéseinket a fenti elméleti bevezetés pontjai szerint építettük fel: egyszerre fókuszáltunk a hosszabb időtartamra és a jelen interaktív metszetére. Vizsgáltuk azokat a megtalálható és a térséget azonosító funkciókat, illetve reprezentációkat, melyek a térség digitális identitását hosszabb távon meghatározzák, illetve felfejtettük azokat a témahálózatokat és kapcsolati hálózatokat, melyek ehhez keretet és dinamikát adnak. Vizsgáltuk továbbá azokat az interaktív, kezdeményező és újításokra nyitott megoldásokat, melyek az online eszközöket használják a hálózatok és közösségek felépítésére, müködtetésére és megtartására, a vonzerő és életminőség javítására.

Első kérdéscsoportunk: Tartozik-e a Zselic régió digitális identitásához egységes platform-, adat- vagy reprezentációs azonositókészlet? A régió karakterisztikája mennyiben épül egymástól független forrásokra? Vannak-e egységes profilelemei, azonosítható térségi szerepei kumulált adatok alapján? Mennyire szerteágazóak online hálózatai és netes reprezentációi? Milyen szerepet játszik az alulról és felülről jövő kommunikáció a régió identitásformálásában és a regionális identitás alakításában?

Második kérdéscsoportunk: Melyek azok az interaktív platformok, ahol a Zselic regionális digitális identitása reprezentálódik? Mennyiben támogatják az interaktív és közösségi kommunikációs rendszerek a régióban élők komfortérzetét, életminőségét és jövőképét? Tartalmi és platformszűréssel mennyiben alkalmasak funkcionális integrációra? 
A kutatás célja egyfelől, hogy összegezze, elemezze és felmutassa a régió már felépült, meghatározó és döntéseket vagy folyamatokat befolyásoló digitális identitását. Ez a vonatkoztatási pont vagy profil támogatja olyan ajánlások megfogalmazását, melyek a régió erősségeire és meglévő hálózataira alapozva tudatos digitálisidentitás-építési koncepció felé vezetnek.

A kutatás módszertana egyrészt gyakoriságok, keresési és megtalálhatósági arányok elemzése, másrészt tartalomelemzés és reprezentációvizsgálat. Mindkét esetben a mintavétel része volt, hogy az adatok és tartalmak hol találkoznak, milyen internetes keresztkapcsolatokkal, egymásra mutató linkekkel milyen témahálózatokat és online reprezentációkat hoznak létre. A mintavétel kézi adatgyüjtésre épült, irányítottan a kutatási kérdések alapján. Szoftveres elemzésre ezúttal nem volt lehetőségünk, folytatás esetén javasolt az erre történő kiterjesztés adatbányászattal és big data módszerekkel. A kiindulópontot a „Zselic” kulcsszó és a hozzá tartozó kulcsszópárok előfordulásai jelentették egy éves periódusra és általános visszakereshetőségre vetítve (1. táblázat). Így jutottunk el a keresők, a közösségi oldalak, a fórumok és az online tömegkommunikáció szerteágazó platformhálózatáig, a hálózati csomópontok és a keresztlinkelések gyakoriságra épülő súlyozásáig, valamint egy összegzéssel a kiemelt tartalmi hálózatok üzenetrendszeréig. A mintavételi eljárásoknál azok a platformok, adatforrások és reprezentációk kaptak hangsúlyt, melyek egyrészt felülreprezentáltak a téma és a térség kapcsán, másrészt relevánsak és részletesebben elemezhetők a keresőtalálatok, a közösségimédia-interaktivitás és -értékelés, a platformhasználat, a témahálózatok és a funkcionális keresztlinkelések alapján.

A kutatásnak több korláttal kellett szembenéznie. Egyrészt a digitális identitás egy aktuális látszat, hiszen online épül fel, szétszórt elemei pedig időben változékonyak. Nem egységes és egyes interakciói az idővonalon eltérnek. Emellett az adatfeldolgozhatósági arány még a legmodernebb, szoftverekkel támogatott feldolgozás esetén is csak részösszefoglalást adhat, valamennyi elem feldolgozhatósága lehetetlen. A teljesebb kép érdekében ezért a kutatási kérdések mentén, irányítottan vezéreltük a mintavételt és a feldolgozást.

Módszertani korlátot jelentett emellett, hogy az adatgyüjtések, keresések és mintavételek IP-címhez, a felhasznált számítógépek keresési és találati előzményeihez kötődnek, felhasználói szokásokhoz rendelt algoritmusoktól pedig nem maradhatnak függetlenek (Pariser 2012). Az idődimenzió és az algoritmusvezérelt meghatározottság miatt a kutatás nem ismételhető meg azonos eredményekkel. Minél nagyobb az időtáv, minél kevesebb számítógépen vagy IP-elérésen ismétlik meg a vizsgálatot, annál inkább eltolódhatnak a kimenetek. 


\section{Eredmények}

\section{A Zselic digitális identitásának azonosítókészlete}

Az első kérdéscsoport arra kérdezett rá, hogy tartozik-e a Zselic régió digitális identitásához egységes platform-, adat- vagy reprezentációs azonosítókészlet. Előzetesen felmerülhet, hogy szükséges-e egyáltalán ilyen egy adott régió számára. Alapfeltételezésünk szerint adott célok mentén feltétlenül szükséges. Cél lehet ugyanis az adott régió jól azonosítható arculatának kialakítása a vonzerő érdekében - hasonlóképpen ahhoz, ahogy egy országimázs felépül. Digitális azonosítók mentén navigáló felhasználók ez alapján döntik el, hogy egy földrajzilag körülhatárolható területre miért érdemes ellátogatni, avagy miért érdemes ott élni. Az egységes összkép itt tehát azt jelenti, hogy jól azonosíthatók különböző lehetőségek, előnyök és egyedi ismérvek. Egyes borvidékek például felismerték ezt a lehetőséget, s akár összefogással közösen építik az egységes, jól definiált arculatot, közös platformmal is. Kutatásunkat ezért tartották fontosnak a régió kiemelt szereplői: előzetesen meg kell ismerni a meglévő adottságokat, hogy abból az integrált kép kialakítható legyen.

A fő kérdés szerint a régió identitásának azonosításához kulcsszavakkal müködő motorok keresési és találati arányait vizsgáltuk, illetve a vizuális reprezentációs eredményeket vetettük össze kumulált éves adatok alapján. Erre építve webes platformokat vizsgáltunk a Zselicet azonosító tematikus webhelyek segítségével. Kiemelt figyelmet kapott a magyar nyelven elérhető Wikipédia-szócikk, mely nemcsak a keresési eredmények különböző változataiban jár élen, hanem a legátfogóbb információkat is biztosítja egy helyen (1. ábra). Eredménye egy azonosítógyüjtemény, melyből visszafejthető a régió identitásának témahálózata.

Kiindulópontként a Wikipédia-szócikket, az első száz Google és Bing webes találati oldalt, illetve a hozzájuk tartozó webes tartalmak kulcsszógyakoriságát

1. ábra: A Zselic Wikipédia-szócikk tartalmi összefoglalása gyakorisági szófelhővel

Content summary of Wikipedia entry about Zselic on frequency word cloud

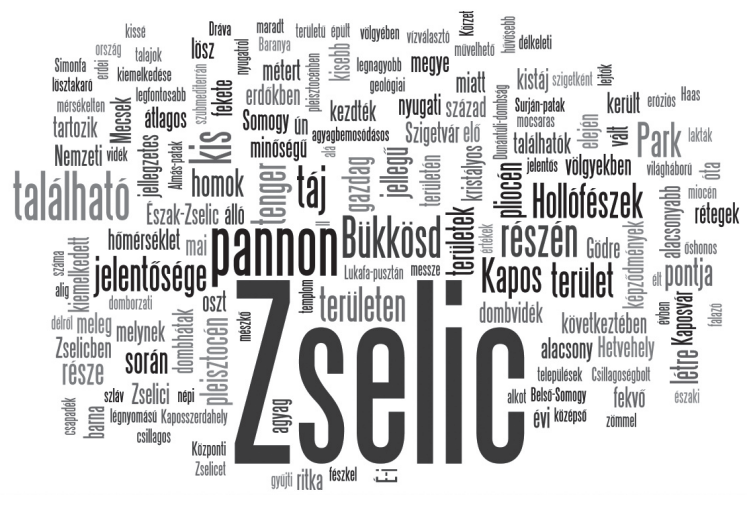


vettük (1. táblázat). A behálózottság két alapvető platformja ez alapján a visitkaposvar.hu és az itthon.hu, melyek a dél-magyarországi régióban betöltött meghatározó turisztikai szerepet emelik ki. Az általános tudásbázis és a médiahangsúly a Wikipédián és az origo.hu-n van a kumulált találatirányítás és a tartalmi támogatottság alapján. A legerősebb és egyben a legsokoldalúbb a bekötés Kaposvárhoz. Itt olyan konkrét, a Zselicben elérhető szolgáltatásokkal találkozhatunk, mint a turizmus alapjaként müködő Csillagpark, a helyi programkínálatban szereplő paintball vagy a helyben üzemelő népszerü autósiskola.

Az 1. táblázatban a TOP 10 találat jelenik meg: ezek a létfontosságú találatok, a felhasználók jellemzően ugyanis itt és így keresik válaszaikat kérdéseikre, legfeljebb harminc találatig nézelődnek vagy egyre bonyolultabb kulcsszó-kombinációkkal próbálkoznak. Ami itt látszik, az egy meghatározó digitálisidentitás-profil, s a téma vagy keresés bejárási útvonalait elsődlegesen befolyásolja.

A keresési listák az elmúlt egy évet és a korábbi keresések kumulált adatait összegzik. A találatok a 2016 első negyedévében mért eredményeket mutatják. Aktu-

1. táblázat: TOP 10 keresés és találat a Google keresőmotor alapján TOP 10 search and hits via Google search engine

\begin{tabular}{l|l}
\hline \multicolumn{1}{c|}{$\begin{array}{c}\text { Keresés - 2016-os kumulált eredmények magyar } \\
\text { IP-címröl }\end{array}$} & \multicolumn{1}{c}{ Találatok magyar IP-címröl (2016. elsö negyedév) } \\
\hline zselic - csillagpark & zselic - wikipedia \\
zselic - szállás & képek - zselic \\
zselic - park & zseliccsillagpark.hu \\
zselic - szabadidőfarm & zselicvölgy szabadidőfarm zselicvolgy.hu \\
zselic - paintball & zselicvölgy szabadidőpark zselicvolgy.hu \\
zselic - térkép & zselic.csillagpark.hu \\
zselic - tv & Kaposvár és a Zselic térkép utazom.com \\
zselic - túraútvonalak & www.zselickincse.com \\
zselic - turistatérkép & www.zselicpaintball.hu \\
zselic - starry sky park & www.zselic-autosiskola.hu \\
\hline \multicolumn{1}{c}{ Keresés - 2016-os kumulált eredmények külföldi } & Találatok külföldi IP-címról (2016. első negyedév) \\
\hline zselic - starry sky park & zselic - wikipedia \\
zselic - Zselic stars & images - zselic \\
zselic - hotel & zseliccsillagpark.hu \\
zselic - park & national landscape protection area darksky.org \\
zselic - szabadidőfarm & Zselicvölgy Szabadidőpark zselicvölgy.hu \\
zselic - paintball & dark skies awareness \\
zselic - térkép & www.darkskiesawareness.org \\
zselic - tv & starry park - all events gotohungary.com \\
zselic - túraútvonalak & zselic.csillagpark.hu \\
zselic - turistatérkép & Kaposvár és a Zselic térkép utazom.com \\
\hline & www.zselickincse.com \\
\hline
\end{tabular}


álisak, hiszen akár egy nagyobb hír, egy új weboldal pár napon belül elmozdíthatja a sorrendet. A vizsgálathoz magyar és külföldi IP-címről is szükséges volt bejelentkezni, hogy az eltérések láthatóak legyenek (lásd az 1. táblázat két oszlopát).

A magyar IP-címről való keresés a hazai turizmust, érdeklődést, avagy érdekeltséget feltételezi. Eszerint a legtöbb felhasználó a Csillagparkra kíváncsi, szabadidős tevékenységet és hozzá szállást keres, különböző módon szeretne navigálni a térségben, illetve felfedezni azt. A B2C kommunikációban ez jól kiaknázható. A Zselic TV-re keresés a helyi lakosság vagy az itt nyilatkozók számára bír jelentőséggel: a regionális identitásra utal. A külföldi IP-címről való keresés esetén az angol nyelv használata jellemző, s ez is inkább a Csillagparkra korlátozódik. A kumulált keresési adatok alapján a régió identitása a turizmushoz kapcsolódik. Emellett a jellemző keresőkifejezések az eladó ingatlanokhoz, idősek otthonához, bölcsődékhez, iskolákhoz, továbbképzésekhez kapcsolódnak. Ezekben érhetők tetten a regionális identitás mindennapjai.

A térség egyedi szolgáltatásaként külön kérésre vizsgáltuk meg a Katica Tanyát. Eredményeink szerint szembetűnő erőfeszítések történtek arra, hogy webes és közösségi kommunikációt folytassanak, ennek láthatósága azonban elmarad a földrajzi elhelyezkedés hangsúlyának hiánya miatt. Az oldalra direkt vagy keresőmotoros érkezéssel eljutva sem derül ki, hogy hol érhető el a szolgáltatás - külön kutatni kell az oldalon belül is, melynek menüsora kevésbé követi a felhasználói logikát.

A találatok alapvetően a turisztikai fókuszt mutatják, de különböző hangsúlyokkal és kiterjesztésekkel. A Wikipédia-szócikk itt kap fontos szerepet. A képi reprezentációk főként természeti, turisztikai és hagyományőrző elemeket mutatnak, avagy vadászathoz, méhészethez, lovagláshoz, biciklizéshez és túrákhoz kapcsolódnak. Utóbbiak intenzív benyomást keltenek. Előtérbe kerülnek a közösségimédia-megosztások is: az élménygyüjtések publikálása az érdekesebb vagy jellemzőbb képi reprezentációkat előrébb hozzák a találatokban - a kattintási gyakoriság, a keresztlinkelés vagy a megosztás szerint. A webes találatok keresései a turisztikai hangsúly mellett már az összetettebb tartalmú zselickincse.hu és zselicvolgy.hu oldalakra mutatnak. A külföldi IP-címes találatoknál a fényszennyezéssel foglalkozó nemzetközi szervezetek és a magyar turizmustámogató országos felületek relevánsabbak, mint a magyar IP-címes kereséseknél.

Az eddigiekre építve a Zselicet azonosító tematikus webhelyeket vizsgáltuk. A cél az volt, hogy először egy azonosítógyűjtemény jöjjön létre webes találati oldalak és aloldalak adatkészletei alapján. Kerestük a tematikus webhelyhálózatok csomópontjait, hogy visszafejtsük a régió identitásának témahálózatát és a regionális identitás helyi életformát generáló webtámogatását. Profilazonosítókat kerestünk elsőként, melyek online meghatározzák és „beégetik" a Zselicet (2. ábra). Az eredmények szerint a földrajzi meghatározottság (Baranya, Somogy, Kapos, dombvidék), a turisztikai attrakciók (Csillagpark, paintball), az aktivitások (túra), a helyi kézműves termékek elérhetősége (zselickincse.hu) és végül a média (Zselic TV) meghatározó vonatkoztatási pontok. 
2. ábra: A Zselic azonosítói webes tartalmak gyakorisága alapján Zselic identifiers based on their web content frequencies

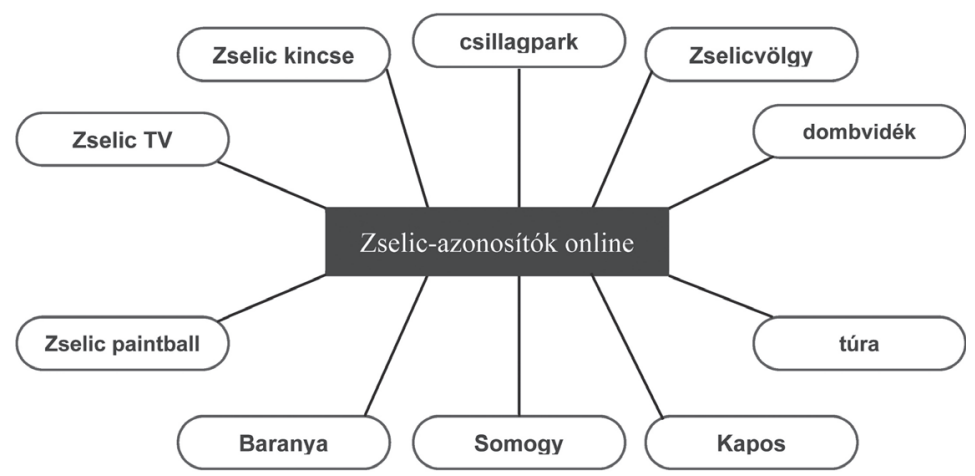

Az azonosítók vizsgálata alapján a látható vagy csak részben látható témacsoportok szürése következett. Az előbbi eredményeket figyelembe véve megvizsgáltuk azokat a főbb területeket, melyeket a legtöbb webes helyen tárgyalnak. Azt találtuk, hogy a témák többsége az üzlet és gazdaság, a kultúrahagyomány-közösségek, valamint a turizmus és a vele szoros kapcsolatban álló természet és látnivalók köré csoportosul. Ezt követően azt vizsgáltuk, hogy ezekre a témakörökre fókuszálva milyen keresztlinkek hangsúlyosak, illetve ezek a linkek mely oldalakra vezetnek. Így találtuk meg azokat a webhelyeket, melyek jellemzően előfordulnak az online Zselic-témahálózatokban. A főbb témákat és területeket sötét tónussal jelöltük, a témahálózat csomóponti webhelyeit világos tónussal, a peremen elhelyezkedő weboldalakat pedig fehérrel kitöltött keretben helyeztük el a 3. ábrán.

A visitkaposvar.hu és a zselickincse.hu meghatározó helyet foglalnak el a tematikus webhelytopológiában. Az üzleti-gazdasági potenciál és a turizmus kapcsolata a zselica.hu és a zselicavolgy.hu oldalakon ér össze, míg a helyi kultúra-hagyomány-közösség tematikus webhelyek a globális és helyi médiaoldalakon keresztlinkelődnek a frekventált szerepű turizmussal - így a facebook.com, a youtube.com, a sonline.hu és a pecsradio.hu oldalakon. A tematikus webhelyhálózat peremén specifikusabb oldalakat találunk. Az üzletnél a méhészet, a lovaglás, a helyi gazdaságok és a vállalkozások platformjai mellett a palyazat.gov.hu utal a térség támogatottságára. A helyiek életét meghatározó programok és lehetőségek szintén a peremen helyezkednek el. A zseliclampasok.hu, az okofalu.hu vagy a lazidomb.hu az online regionális identitást erősítik.

A Zselic-azonosítók meghatározása és a tematikus webhelyek kijelölése után mélyebbre ásva a Zselic témahálózatát tártuk fel. Ehhez az előbbi szüréssel kapott weboldalak tartalmait adatosítottuk és csoportosítottuk. A tartalomelemzés célja volt a főoldalak és a találati oldalak részletes vizsgálata, a témahálók összegzése és gyakoriság, illetve relevancia szerinti szűrése. Az összegző ábrán a főbb témahálózati csomópontokat sötét tónussal jelöltük, 
3. ábra: A Zselicet azonosító tematikus webhelyek webes gyakoriság, keresztlinkelések és releváns online tartalmak elemzése alapján Thematic web content with Zselic identifiers by their frequencies, crosslinks and relevant online contents

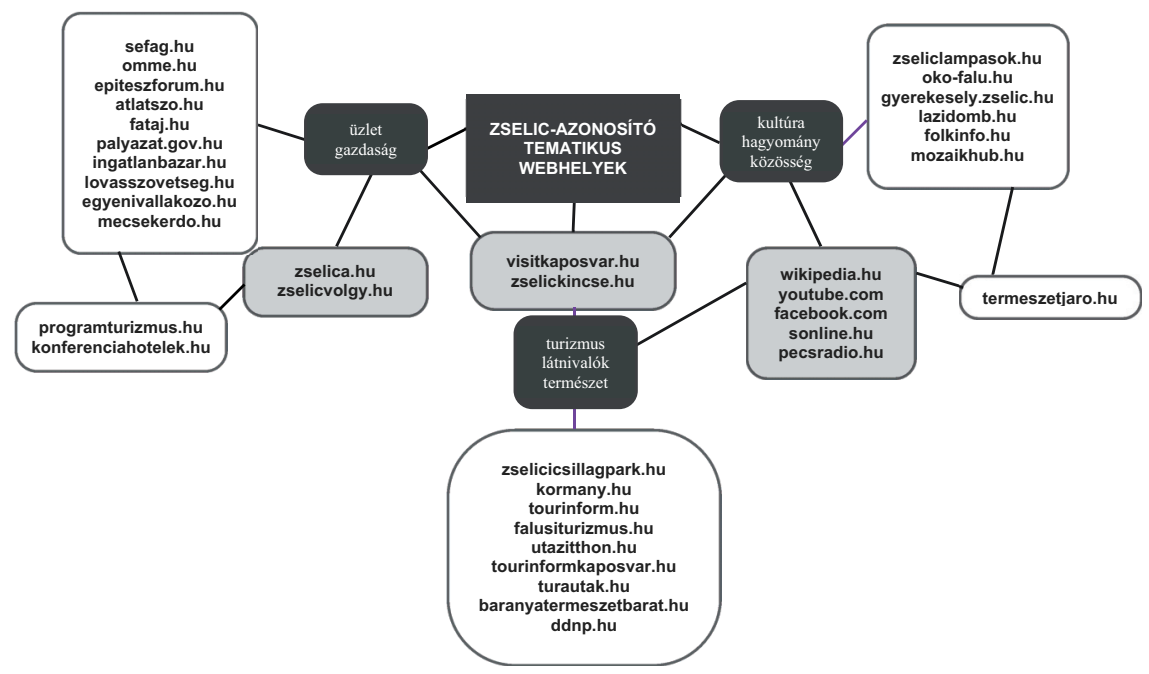

míg az ezekhez kapcsolódó témaelágazások fehér színnel kitöltött keretbe kerültek (4. ábra).

A regionális erőforrások a terület- és vidékfejlesztéshez, a fafeldolgozáshoz és az építészethez kötődnek. Ide tartozik a vadászat és a méhészet is, de ennek szerepe vonzerőként és egzotikumként integrálódik a turizmus témahálózataiba. A napi élet és rutinok ettől független témahálózatban jelennek meg a hiva-

4. ábra: A Zselic webes támogatású témahálózata

The web-driven content network of Zselic

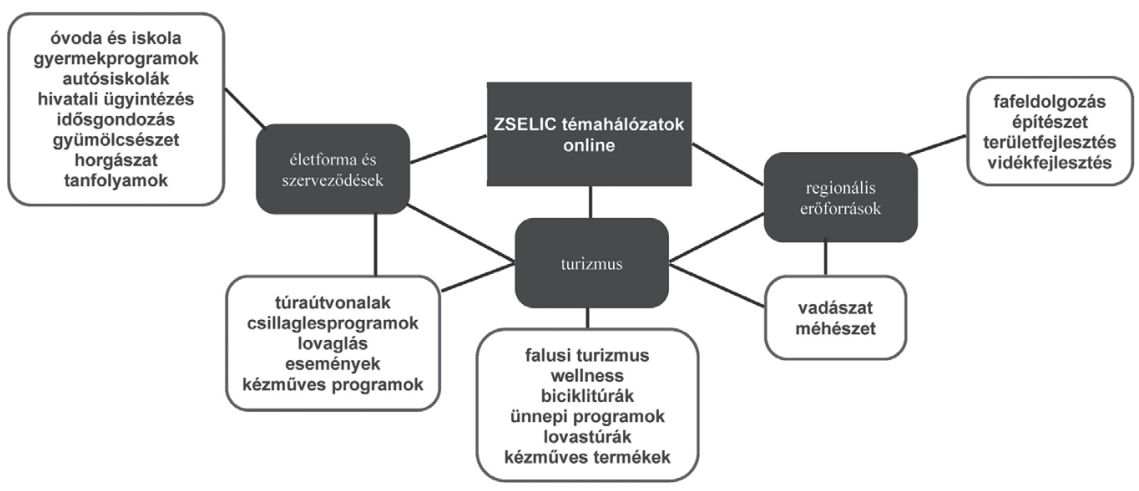


tali ügyintézéstől a gyermek- és idősgondozáson keresztül a tanfolyamokig. Elgondolkoztató eredmény, hogy a gyümölcstermesztés és a horgászat miért nem kapcsolódik szorosan a vadászathoz és méhészethez. E témák összekötése további lehetőséget jelent a térség turizmusa számára, illetve befektetések esetén a regionális erőforrások intenzívebb kihasználására. A túraútvonalak, a csillaglesprogramok, a lovaglás, a kézmüvesség és a rendezvények, illetve események már bekapcsolódnak mind a helyiek, mind a turizmus életébe. Erősségei egyszerre építik a régió identitását és a regionális identitást. A Zselic digitális identitásában mértékadó szerepet játszó turizmus van ismét meghatározó csomópontban. Ez köti össze a regionális erőforrásokat és a helyiek életmódját, szerveződéseit közvetlenül vagy közvetetten. A túrák, a kézművesség, az ünnepi programok hangsúlyosak ebben. Az ide látogatók ezeken a pontokon találkozhatnak a helyi közösségekkel. A falusi turizmus és a wellness elsősorban a régió identitását erősítik.

Külön vizsgáltuk a helyiek életét, komfortérzetét, beágyazódását és itt maradását szolgáló webhelyeket, melyek a Zselichez kapcsolódó regionális identitásuk építésében szerepet játszanak. A zselickincse.hu ebben csomópontként funkcionál: a helyi ügyek intézésében, illetve a kultúrában és művelődésben is összekötő platform. Külön vizsgálva a hivatali ügyintézést, a földhivatalt, a gyermekvédelmet és a más településhez kapcsolódó hivatalos funkciókat, néhány település erősebben behálózott képet rajzol ki: Bárdudvarnok, Bőszénfa, Kaposmérő, Mozsgó, Sántos, Simonfa, Zselicszentpál, Zselickisfalud szerepe kiemelkedik a többi település közül online eszközkészletével. Többen keresik ezeket, klikkelnek rájuk, nagyobb oldalforgalmat bonyolítanak a többihez képest. A kultúra és művelődés webhelyei elsősorban a gyermekekhez és az iskoláztatáshoz adnak hivatkozást. Méltatlanul nem került elő eddig az egyud.kaposvar.hu oldal, mely művelődési intézmények, szolgáltatások, szakkörök, civil szervezetek és a felnőttképzés összefoglaló platformja. Bár elsősorban Kaposvárhoz kötődik, komoly lehetőségeket nyújthat a zselici térségnek az aktívabb bekapcsolódáshoz. Éppígy az ugyanarra a webhelyre mutató jartalmaritt.hu és visitzselic.hu, azaz a Kaposvár és Zselic Vidéke Turisztikai Desztináció Menedzsment oldalainak szerepe is jelentősen bővíthető. A szennai Lázi-domb Kulturális Egyesület rendezvényeket, szabadidős és sporteseményeket, információáramlást, néprajzi gyüjteményt és környezetvédelmi szemléletet biztosít, melynek a jelenléte szintén bővíthető.

Csak irányított kereséssel jutottunk el a vallási identitás kérdéséhez: a térség identitásának témahálózatában a vallás nem kap online látható hangsúlyt. A kaposvár.egyházmegye.hu adott valamennyi eligazítást a vallásgyakorlat egyes helyszíneiről, illetve a református közösségek számára érhető el rendszeresen frissített tartalmú, az aktuális eseményeket hirdető webhely refdunantul.hu címmel. Emléktúrák és zarándokutak egészítik ki ezt a képet.

Az első kérdéscsoportra adott rövid válaszunk az, hogy a Zselic régió digitális identitásához nem tartozik egységes platform, ellenben vannak jól defini- 
álható webes csomópontjai. Adat- vagy reprezentációs azonosítókészlete alapján témahálózatai és erősségei koncentráltan jelennek meg. Karakterisztikája bár gyakran egymástól független forrásokra épül, alulról és felülről jövő kommunikációra épít, egyes felületek mértékadóak és meghatározóak, így elsősorban a zselickincse.hu és a visitkaposvar.hu. Az itthon.hu gyüjtőoldala, a wikipedia.hu, a facebook.com, a youtube.com globális keretplatformjai, illetve a lokális érintettségủ pecsradio.hu és sonline.hu kiváló, tovább építhető médiacsatornákat, PR- és marketingkommunikációs lehetőségeket, valamint online közösségépítési színteret biztosítanak. A fő profil a webes digitális identitás alapján a turizmus, ezen belül a hazai és külföldi turizmus számára is a Csillagpark. A turizmus mellett a helyi gazdaság tematikus összefoglalása a zselica.hu, zselicvolgy.hu webhelyekhez hálózódik be, ez erősíthető, éppúgy, ahogy a vadászat és méhészet tematikája összeköthető a gyümölcstermesztés és a horgászat webes tartalmaival. A helyi közösségek és hálózatok tematizált felülete és egyben motorja a zselickincse.hu, melynek szerepe más területeken is hangsúlyos.

\section{A Zselic digitális identitásának interaktív platformjai}

A második kérdéscsoport arra kérdezett rá, hogy melyek azok az interaktív platformok, melyeken a Zselic regionális digitális identitása reprezentálódik. Itt egyrészt figyelembe vettük az első kérdéscsoportra kapott válaszokat, másfelől főleg a közösségi hálózatok, illetve a közösségimédia-platformok felől vizsgálódtunk. Kerestük a térség közösségi-kulturális azonosítóit, a helyiek online kommunikációs hálózatait és csoportjait. Vizsgáltuk azt is, hogy a magánszemélyek és a vállalkozások mennyire nyitottak az új, interaktív és a térséget támogató online eszközökre és fejlesztésekre a digitális láthatóság növelésének érdekében.

Az első lépés adott volt: a Facebook közösségi platformon kezdtük a vizsgálódást. Hazánkban a lakosság több mint fele használja rendszeresen, rendelkezik rajta profillal. Itt két irányból vizsgálódtunk: kerestük azokat az intézményeket, cégeket, szervezeteket, akiknek saját oldaluk van a felületen és rajongótábort építenek. Kerestük azokat a csoportokat, illetve eseményeket is, melyek a közösségi élet részleteibe nyújtanak betekintést.

Kezdve a legnagyobb rajongói közösségi oldalakkal, első körben a „Zselic” kulcsszó és a hozzá tartozó kulcsszópárok felől indulva kiszűrtük azokat, melyeknek csak néhány látogatója van és/vagy nincs frissülő tartalmuk. Ezekkel részletesen nem foglalkoztunk. A fennmaradók közül külön vizsgáltuk a nagyobb felhasználói létszámot megmozgató oldalakat és a kisebb rajongótáborral bíró, specifikus profilokat. A kritikus határ a 400 fö elérése: efölött mindössze hat oldal van. Az ez után következők száz körüli vagy jóval kevesebb érdeklődővel rendelkeznek.

A 400 fö feletti rajongóval rendelkező Facebook-oldalak különbségeket és hasonlóságokat is mutatnak. Vizuális megjelenésük eltérő, közös elemeket, például közös logót vagy azonosítót nem tartalmaznak, a képek és albumok átfedé- 
se nem jellemző, a professzionális megjelenés mellett inkább az amatőr megoldások fordulnak elő. Közös viszont az interaktivitás részleges vagy szinte teljes hiánya. A lájkok esetenként jelennek meg, a hozzászólás lehetőségeit csak néhány felhasználó vagy rajongó alkalmazza. A gyakorisági viszonyok megmutatására ezeknek a Facebook-oldalaknak a szövegeit, posztjait, kommentjeit szófelhőn dolgoztuk fel (5. ábra).

Az első helyen a hajmási Zselic Szabadidőfarm található 3645 rajongóval vagy követővel. A 2014 óta működő oldal a fotókra és a Zselic-életérzés átadására törekszik, programokat és gasztronómiai élményeket népszerüsít. Ez az egyetlen oldal, ahol 100-150 lájk feletti elérés is található, valamint a tömegmédia (RTL Fókusz) figyelmét is felkeltette. A kevés számú hozzászólás azonban nem jelez bevonódást vagy felhasználói lojalitást. A második helyen álló Zselic és Somogy Kincse szintén 2014 óta müködik, interaktív szerepe nem értékelhető. Keresztény ünnepeket és értékeket közvetítenek tartalmai, ellensúlyozva a vallásiidentitás-vizsgálat korábban bemutatott visszafogott eredményeit. Vélhetően magánszemély működteti, talán hobbiprojektként: az oldal átkötései a tartalomtól független zenei vagy más érdeklődést mutatnak. A Zselici Csillagpark szintén dobogós. Kiemelendő, hogy erről az oldalról ötös skálán ötcsillagos értékelések születtek. Rajongóik, ha nem is igazán interaktívak, de a szöveges visszajelzések alapján a programokat követő és visszatérő vendégek. Az oldal frissülő tartalommarketingje magas színvonalon támogatja a szolgáltatást, illetve alkalmazza a Facebook-eseményként való meghirdetést, amiből jól látszik a rendszeres érdeklődői létszám. Létezik egy Zselici csillagos égbolt park is, melyet a Nemzetközi Csillagos Égbolt Szövetség alapított, s inkább csillagászati jelenségekkel foglalkozó közösségként működik 2010 óta. Tartalmait láthatóan

5. ábra: A 400 főnél több rajongóval rendelkező, Zselichez kapcsolódó

Facebook-oldalak tartalmának gyakoriságai szófelhőn

Zselic Facebook pages with 400+ likes: content frequencies on a word cloud

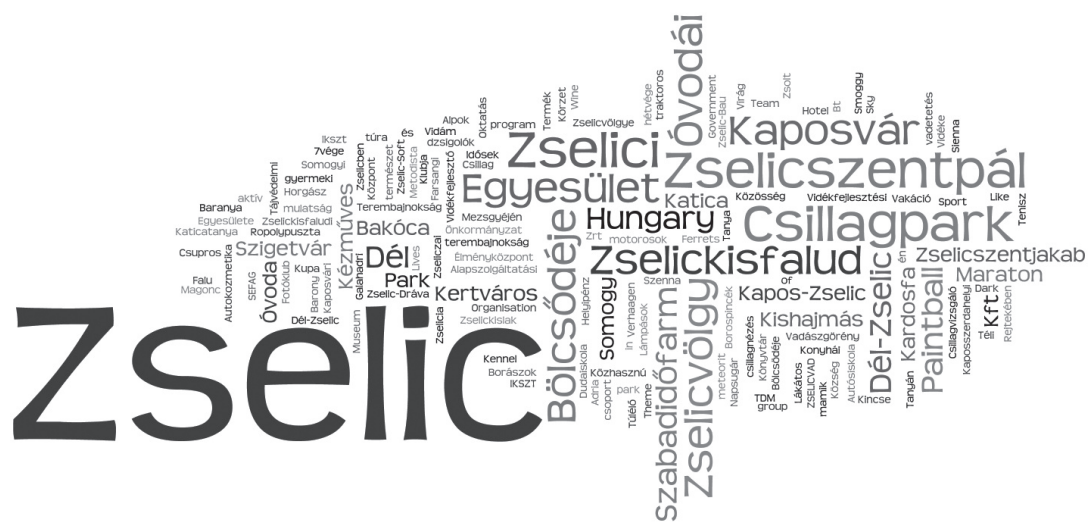


szívesen megosztják a téma iránt elkötelezettek. A Zselic közösség nyilvános oldal üzenete szerint azon embereket igyekszik hálózatba szervezni, akik ismerik vagy szeretnék megismerni a zselici dombvidék sűrü erdőit, kalandos parkjait és ragyogó csillagait. Kifejezetten eseményekre, ünnepekre és túrákra fókuszálnak, alkalmanként akár húsz visszacsatolást is kapnak egy-egy poszthoz. A vezető rangsor végére érve már speciális, helyieknek szóló, de komolyabb rajongótábort építő oldalak vannak. A Dél-Zselic SE Szigetvár birkózó egyesület és a Zselic Autósiskola Bt. népszerüek, ezeket sporteredmények vagy tanfolyamok és vizsgaeredmények miatt követik a felhasználók, akik jellemzően nem interaktívak a megosztott tartalmakkal kapcsolatban.

Külön vizsgáltuk azokat a Facebook-csoportokat, melyek vagy nyitott, azaz más felhasználók számára is elérhető formában építik hálózataikat és tartalmaikat, vagy zárt közösségként működnek. A nyitott csoportok közül élen járnak a vadászgörényekért (188 tag) és a paintballért rajongók (123 tag), illetve a Zselici motorosok (119 tag). Zárt csoportokban nagyobb létszámban érik el egymást a Cibere táncklub tagjai (32 tag) és a Zselici mamik (86 tag). A felsorolt csoportok jól mutatják a helyi szabadidős tevékenységek és az alulról építkező kapcsolatépítés mintázatait.

A Facebookon túl a közösségimédia-használat nem mutat egységes képet. Saját Youtube- vagy más videócsatornával nem rendelkezik a Zselic, egyes rendezvények videóit magánszemélyek vagy intézmények osztják meg, ezek mellett turisztikai tartalmakkal találkozhatunk képgyűjtő és videómegosztó oldalakon. Blogok vagy blogtartalomra építő oldalak is találhatók (ejszakaitajkep.hu), illetve Pinterest-, Tumblr-, Twitter-, Instagram-csatornákon is előfordulnak releváns tartalmak. Ezek leginkább turisztikai élményekre építenek, vagy egy-egy témát dolgoznak fel a térségből. A közösségi médiában meghirdetett események erősíthetők, pl. maratonfutás, művelődési házak vagy szervezetek, csoportok programjai.

Külön vizsgáltuk azt, hogy a magánszemélyek, közösségek vagy vállalkozások mennyire nyitottak az új, interaktív és a térséget támogató digitális eszközökre és fejlesztésekre az online láthatóság növelése érdekében. A turizmus felől közelítve a szállásadó oldalakon (elsősorban booking.com) megjelennek szolgáltatók. Értékeléseik általában magasak, tízből nyolc vagy kilenc felettiek (pl. Zselicvölgy Szabadidőfarm, Hajmás 9+, Hotel Kardosfa Zselickisfalud 9+, Kastélyszálló Szarkavár, Kaposújlak 8+). Az AirBnB globálisan népszerű szolgáltatása Ibafán és Somogyviszlón talált táptalajt, itt is vannak további lehetőségek, elsősorban a falusi turizmus kiterjesztéséhez.

Az online bekötések mellett kíváncsiak voltunk arra is, hogy a weben túl mennyire merészkednek a helyi szolgáltatók az alkalmazások világába. Az élen a Handmade Tastes - Kézműves Termékek alkalmazás jár, mely Android és iOS rendszerben is müködik. A Land-Art Kft. hozta létre és a Zselic Kosara Egyesület webfelülete szolgál hátteréül. Alapvető céljuk a Dél-dunántúli régióban, azon belül is a Zselici tájegységben fellelhető és előállítható mezőgazdasági és kéz- 
műipari termékek összegyűjtése, fejlesztése, hatékonyabb termelésük ösztönzése, egységes arculatú megjelenítése, piacra jutásuk segítése. A Zselici Csillagpark alkalmazása inkább a szemléltetésre és az élményre helyezi a hangsúlyt: a Google Mapshez hasonló megoldást az ürbeli séták illúziójához alakította 3D-ben. Végül a Zselicvölgy Szabadidőfarmot érdemes megemlíteni saját alkalmazással, mely az utazás-előkészítést és szállásfoglalást támogatja. További innovációval, például drónnal készített imázsfilmmel nem találkoztunk, illetve speciális (öko, wellness) alkalmazások híreivel sem. A geolokáció és az augmentált megoldások lehetőségei szintén hordoznak tartaléklehetőségeket a jövőben.

A második kérdéscsoportra adott rövid válaszunk az, hogy a Zselic regionális digitális identitása interaktív platformokon reprezentálódik, de csak egyes metszetei láthatók (azok is felülreprezentálva a Facebookon), kevés interaktivitással. Az interaktív és közösségi kommunikációs rendszerek támogatják a régió komfortérzetét, tartalmi és platformszüréssel integrációra alkalmasak, ami további kiterjesztéssel erősítheti a regionális identitást. A jövőképhez tartozó kísérletek ígéretes megoldásai megkezdődtek, bővítésük javasolt.

\section{Összefoglalás}

Eredményeink szerint az alulról és a felülről épülő digitális lábnyomok platformszinten szerteágazóak, a funkcionális oldalak, a témahálózatok és a közösségi média összeköttetései részben hiányoznak. Egyes globális vagy helyi médiaplatformok integrátorként müködnek, hálózataik azonban gyakran peremterületre kerülnek.

A Zselic régió digitális identitásához nem tartozik egységes platform vagy közös platformok. Jól definiálható webes csomópontok, keresztlinkelt tartalmak, kumuláltan jellemző keresési és találati adatok, illetve vizuális reprezentációk alapján témahálózatok és erősségeik koncentráltan vizsgálhatók. A gyakran egymástól független forrásokra épülő, alulról és felülről is jövő kommunikációból kialakuló karakterisztika mértékadó és meghatározó webes-tematikus hálózatot hoz létre. A zselickincse.hu, a visitkaposvar.hu. a zselica.hu, a zselicvolgy.hu komoly potenciált jelentenek az erősebb csomópontok létrehozásában, melyet a wikipedia.hu, az itthon.hu a facebook.com, a youtube.com a pecsradio.hu, és a sonline.hu médiacsatornái erősíthetnek.

A fó profil a webes digitális identitás alapján a turizmus. Kiemelt szolgáltatási és tartalmi csomópontja több platformon is a Csillagpark. Ikonikus azonosító, melynek szerepe tovább erősíthető. A turizmus mellett a helyi gazdaság tematikus összefoglalása és összefogása lehet újabb célkitűzés.

A zselici regionális identitás földrajzilag a déli területekről reprezentálódik inkább a közösségi médiában. Az interaktivitás lehetősége, a csoportok és közösségek online támogatása növeli a régióban élők komfortérzetét, tartalmi és 
platformszüréssel integrációra alkalmas, ami továbbfejlesztéssel erősítheti a regionális identitást. Az innovációs kísérletek alkalmazások formájában jelennek meg, további bővítések lehetségesek ezen a területen.

\section{Ajánlások}

A kutatás alapján a következő ajánlások fogalmazhatók meg:

- A meglévő, kumuláltan jó keresési és találati előzményekkel bíró, tartalmilag és funkcionálisan összefoglaló jellegű webes csomópontok erősítése javasolt. A zselickincse.hu, visitkaposvar.hu, zselica.hu, zselicvolgy.hu, egyud.kaposvar.hu, jartalmaritt.hu, visitzselic.hu, lazidomb.hu a turizmus és a helyi szolgáltatások, illetve cégek támogatója, keresztlinkelésük további előnyöket nyújt.

- A Csillagpark szerepének kiemelése, vizuális szimbólummal vagy logóval való felruházása a Zselic régió azonosíthatóságát növeli.

- A komoly vonzerőt jelentő Katica Tanyát földrajzi beágyazottság szerinti tartalommal és keresőoptimalizálással szükséges újragondolni, weboldaluk menüpontjai átstrukturálhatók a célcsoportok szerint, közösségi oldaluk és más Zselic-oldalakkal való összekötésük erősítheti szerepüket a régióban.

- Magyar és idegen nyelvű (elsősorban angol, német, horvát) tartalmak bővítése, illetve frissítése javasolt.

- Az online hálózatok tematikusan összetartó csomópontjai tovább erősíthetők és integrálhatók az erőforrás-felhasználás, a szolgáltatáskínálat vagy a falusi turizmus támogatásával - többek között a vadászat, horgászat, gyümölcstermesztés, méhészet, kézművesség, valamint az események és rendezvények kiemelésével.

- A médiafunkció és a megosztási funkció előmozdíthatja az interaktivitást és láthatóbbá teheti a közösségi hálózatokat.

- Újítások bevezetése és a fiatalabb generációk platformjainak bevonása ajánlott: drónnal készíthető imázsfilm, Instagramon vagy Pinteresten profilépítés, alkalmazások bővítése vagy más forma.

\section{Köszönetnyilvánítás}

Ezúton szeretnék köszönetet mondani a Budapesti Gazdasági Egyetem Kutatóközpontjának az EMMI-26130-2/2013/TUDPOL számon biztosított kutatási feltételekért. 


\section{Irodalom}

Faragó L. (2007): Térstruktúra: térideák és megvalósításuk a településhálózat-fejlesztésben. Tér és Társadalom, 4., 21-38.

Fehér K. (2014): Milyen stratégiák mentén épül fel a digitális identitás? Feltáró kutatási szakasz: a munkavállalás előtt álló egyetemisták. Médiakutató, 2., 139-154.

Fehér K. (2015): Interkonnektivitás, új média és digitális identitás a regionális kutatásban. Koncepcionális megközelítés ajánlásokkal. Tér és Társadalom, 4., 27-41. http://doi.org/bxsj

Gantz, J., Reinsel, D. (2011): Extracting value from chaos. https://www.emc.com/collateral/analystreports/idc-extracting-value-from-chaos-ar.pdf (Letöltés: 2016. december 8.)

Gáspár T. (2005): Idő-tér-korszakváltás. In: Hideg É. (szerk.): Társadalmi tér, idő, téridő a jövőkutatásban. Budapesti Corvinus Egyetem Jövőkutatás Tanszék, Budapest, 82-107.

Larose, D. T., Larose, C. D. (2011): Discovering knowledge in data. An introduction to data mining. 2nd edition. John Wiley \& Sons, New Jersey

Pariser, E. (2012): The filter bubble. Penguin Press, New York http://doi.org/bxsk 